Annals of Warsaw University of Life Sciences - SGGW

Land Reclamation No 48 (1), 2016: 67-77

(Ann. Warsaw Univ. Life Sci. - SGGW, Land Reclam. 48 (1), 2016)

\title{
The occurrence of hot weather in the Lublin-Felin and Czesławice in relation to atmospheric circulation (1966-2010)
}

\author{
KRZYSZTOF BARTOSZEK ${ }^{1}$, ALICJA WĘGRZYN² \\ ${ }^{1}$ Department of Meteorology and Climatology, Maria Curie-Skłodowska University \\ ${ }^{2}$ Department of Agrometeorology, University of Life Sciences in Lublin
}

\begin{abstract}
The occurrence of hot weather in the Lublin-Felin and Czestawice in relation to atmospheric circulation (1966-2010). The paper describes the occurrence of hot $\left(t_{\max } 25.1-30.0^{\circ} \mathrm{C}\right)$ and very hot days $\left(t_{\max }>30^{\circ} \mathrm{C}\right)$ in Lublin-Felin and Czesławice in the years 1966-2010. The analysis covers the long-term variability of such days, and duration of heat waves. Their circulation conditions were also determined, with indication of circulation types during which the probability of occurrence of hot and very hot days was the highest. In the study area, hot days occurred from April to September, and very hot days from May to August, with the highest frequency in July in both cases. In the period from 1991 to 2010, a considerably higher number of cases of very hot days were recorded than in the 1970s and 1980s. Moreover, they occurred in increasingly long sequences, contributing to more frequent occurrence of unfavourable thermal and humid conditions during the growing season of plants. The highest probability of occurrence of hot and very hot days was determined for circulation types with airflow from the southern sector, and the lowest from the northern sector. Should the upward trend in the frequency of very hot days continue, the risk of the effect of such unfavourable thermal conditions on the health and well-being of tourists and patients of the health resort in Nałęczów will also increase.
\end{abstract}

Key words: hot days, very hot days, heat waves, circulation types, air advection

\section{INTRODUCTION}

Over the last several decades, an increase in mean annual air temperature has been observed in a number of regions of the world. It was manifested in among others increasingly warm days and nights (Vose et al. 2005, Morak et al. 2011). Moreover, in Europe in the early $21^{\text {st }}$ century, summer periods were distinguished by the occurrence of exceptionally long heat waves (Rebetz et al. 2009). In Polish literature on the subject, the variability of occurrence of hot weather is usually studied in terms of a climatic event (Morawska-Horawska 1991, Filipiuk and Kaszewski 2000, Kaszewski et al. 2007, Twardosz 2009, Kossowska-Cezak 2010), or effect on human health and well-being (Kuchcik 2006, Błażejczyk and McGregor 2007, Koźmiński and Michalska 2011). An increased frequency of occurrence of hot days also affects the primary sectors of the economy, including agriculture. According to Żmudzka (2004), the coincidence of exceptionally high air temperature values with very low precipita- 
tion totals at the end of the $20^{\text {th }}$ century caused the occurrence of long-lasting dry periods in Poland, i.e. conditions exceptionally unfavourable for agricultural production. Weakening of plants as a result of thermal stress is considered to increase the probability of occurrence of diseases and crop pests (Lipa 2008).

The Lublin Region has a high agricultural production potential. Therefore, the forecasted increase in the frequency and intensity of occurrence of heat waves can be of high importance for this sector of the economy. The objective of this paper is to describe the occurrence of hot and very hot days in Lublin-Felin and Czesławice in the period from 1966 to 2010 . The analysis covers a long-term variability of such days, the tendency of changes in their occurrence, length of heat waves, and atmospheric circulation conditions.

\section{MATERIAL AND METHODS}

The study was based on daily values of maximum air temperature from the period 1966-2010, measured at 18 UTC by a thermometer in a standard meteorological shelter ( $2 \mathrm{~m}$ above the ground). The data came from two weather stations, one located at the eastern boundary of the city of Lublin, in the Felin district $\left(51^{\circ} 14^{\prime} \mathrm{N}, 22^{\circ} 38^{\prime} \mathrm{E}, 215 \mathrm{~m}\right.$ a.s.l.), and the other located in Czesławice $\left(51^{\circ} 18^{\prime} \mathrm{N}\right.$, $22^{\circ} 16^{\prime} \mathrm{E}, 205 \mathrm{~m}$ a.s.1.), approximately $4 \mathrm{~km}$ north-east of the health resort in Nałęczów (Fig. 1).

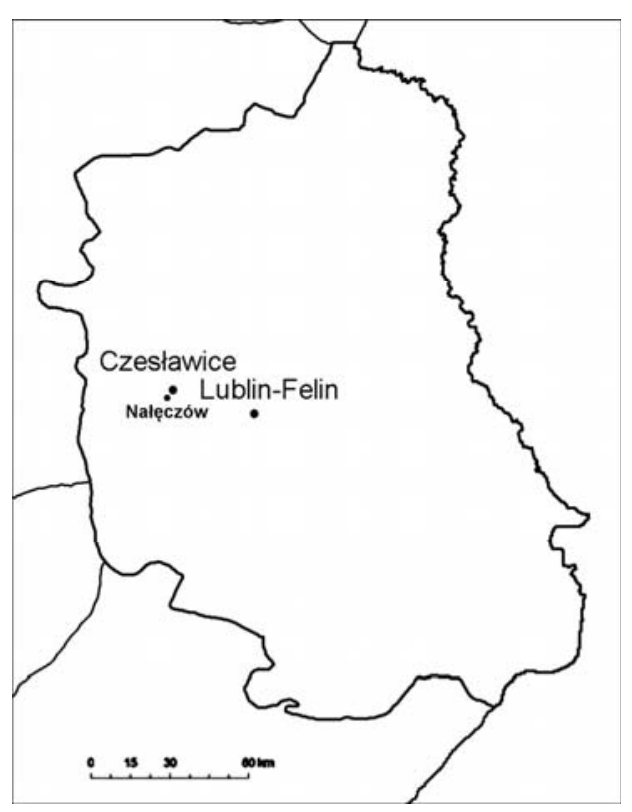

FIGURE 1. Location of meteorological stations used in the study

The study involved the description of hot $\left(t_{\max } 25.1-30.0^{\circ} \mathrm{C}\right)$ and very hot days $\left(t_{\max }>30^{\circ} \mathrm{C}\right)$, and the determination of the frequency of occurrence of heat waves (at least 3 days with $t_{\max }>30^{\circ} \mathrm{C}$ ). The analysis of temporal trends in the mentioned descriptions was also performed. The statistical significance of trend coefficients was determined with the application of the nonparametric Mann-Kendall test.

The atmospheric circulation conditions of hot and very hot days in the period from June to August were presented with the application of the classification of circulation types over the Lublin Region (Bartoszek 2012). In the catalogue used in the study, each day was referred to one of 27 circulation types obtained with objective method based of gridded 
mean sea level pressure over Central Europe at 12 UTC. The classification differentiates between 8 directional cyclonic, transitional, and anticyclonic types, and three non-directional: cyclonic, anticyclonic, and undefined (Table 1).

TABLE 1. Classification of circulation types for the Lublin Region

\begin{tabular}{|c|c|}
\hline Symbols & Description \\
\hline $\begin{array}{c}\text { Nc, NEc, Ec, SEc, Sc, } \\
\text { SWc, Wc, NWc }\end{array}$ & $\begin{array}{c}\text { directional } \\
\text { cyclonic types }\end{array}$ \\
\hline $\begin{array}{c}\text { No, NEo, Eo, SEo, So, } \\
\text { SWo, Wo, NWo }\end{array}$ & $\begin{array}{c}\text { directional } \\
\text { transitional types }\end{array}$ \\
\hline $\begin{array}{c}\text { Na, NEa, Ea, SEa, Sa, } \\
\text { SWa, Wa, NWa }\end{array}$ & $\begin{array}{c}\text { directional } \\
\text { anticyclonic types }\end{array}$ \\
\hline C & $\begin{array}{c}\text { cyclonic } \\
\text { non-directional type }\end{array}$ \\
\hline A & $\begin{array}{c}\text { antiyclonic } \\
\text { non-directional type }\end{array}$ \\
\hline X & $\begin{array}{c}\text { undefined } \\
\text { non-directional type }\end{array}$ \\
\hline
\end{tabular}

\section{RESULTS AND DISCUSSION}

In the period from April to September, the contribution of hot days in Czesławice amounted to $17.6 \%$, and in Lublin-Felin to $15.9 \%$ of all days of the warm halfyear. Their mean annual number was also similar, amounting to approximately 30 days (Table 2). The first hot days already occurred in the third decade of April, with the maximum frequency in 2000 (4 cases). The average number of hot days in May has been 3 days - their highest frequency (10-11 days) occurred in 1979, 1998, and 2007. In June, at least one hot day occurred in every year of the analysed multiannual period except for 1974 and 1980. In the vicinity of both of the meteorological stations, more than 10 hot days occurred in June 1972, 1977, 1979, 1999, 2000, 2006, and 2007. In Czesławice, the maximum was reached in 1972 (15 days), and in Lublin-Felin in 1999 (20 days). The highest frequency of occurrence of hot days was recorded in July (9-10 days on the average). Their maximum number was recorded in Czesławice in 2001 (20 cases) and in 1975 (19 cases). A slightly lower frequency of hot days was observed in August (Table 2). Their exceptionally high frequency in the month occurred in 2002 (25 days in Lublin-Felin and 21 days in Czesławice). In September, hot

TABLE 2. Characteristics of hot days in Czesławice and Lublin-Felin

\begin{tabular}{|c|c|c|c|c|}
\hline \multirow{3}{*}{ Months } & \multicolumn{4}{|c|}{ Hot days $\left(t_{\max } 25.1-30.0^{\circ} \mathrm{C}\right)$} \\
\hline & \multicolumn{2}{|c|}{ Czesławice } & \multicolumn{2}{|c|}{ Lublin-Felin } \\
\hline & sum & mean & sum & mean \\
\hline April & 8 & 0.2 & 8 & 0.2 \\
\hline May & 133 & 3.0 & 123 & 2.7 \\
\hline June & 291 & 6.5 & 266 & 5.9 \\
\hline July & 460 & 10.2 & 419 & 9.3 \\
\hline August & 452 & 10.0 & 405 & 9.0 \\
\hline September & 113 & 2.5 & 91 & 2.0 \\
\hline October & $\cdot$ & $\cdot$ & 2 & 0.0 \\
\hline Sum / Mean & 1457 & 32.4 & 1314 & 29.2 \\
\hline
\end{tabular}


days were considerably rarer (less than 3 per month on the average). Their highest number (6-8 cases) was recorded in 1967, 1975, 1982, 2002, and 2005. The latest case of occurrence of hot days was observed in Lublin-Felin in $1966\left(6-7^{\text {th }}\right.$ October), and in Czesławice in 1991 ( $30^{\text {th }}$ September). At the annual scale, the conditional probability of occurrence of hot days greater than $25 \%$ concerned the period from the end of the third decade of June to the end of August, with the maximum frequency (approximately 40\%) in the first decade of August (Fig. 2). $20^{\text {th }}$ century (Fig. 3). The meteorological station in Lublin-Felin was outside of the range of the "urban heat island" until approximately 1990 . Over the last 20 years, however, along with the development of infrastructure, the vicinity of the weather station was increasingly affected by the urban area. This might have caused a stronger growing tendency in the number of hot days.

Very hot days occurred in the vicinity of both of the meteorological stations much more seldom than hot days (Table 3). In the first two decades of the

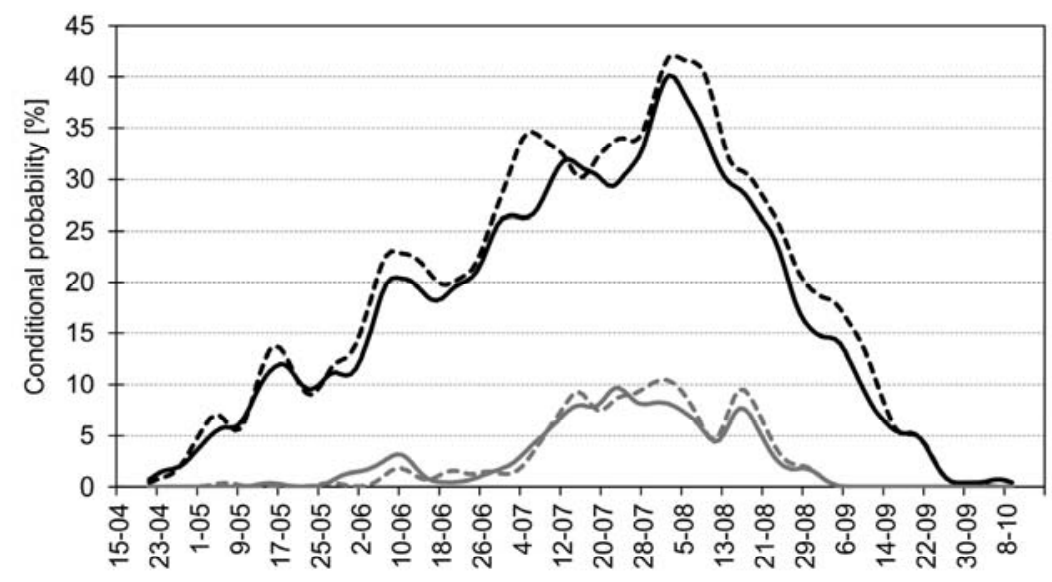

Days in the year

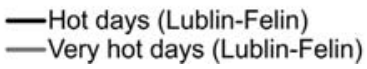

---Hot days (Czesławice) ---Very hot days (Czesławice)

FIGURE 2. The conditional probability [\%] of occurrence of hot and very hot days in different days of the year (values smoothed by 13-day Gaussian filter)

In the study period, a statistically significant $(\alpha=0.01)$ upward trend was only recorded in the case of Lublin-Felin, determined by a higher frequency of occurrence of hot days at the end of the analysed multiannual 1966-2010, in certain summer periods, such days did not occur at all. Their considerably higher frequency was only recorded from the early 1990's, with a maximum in 1994 


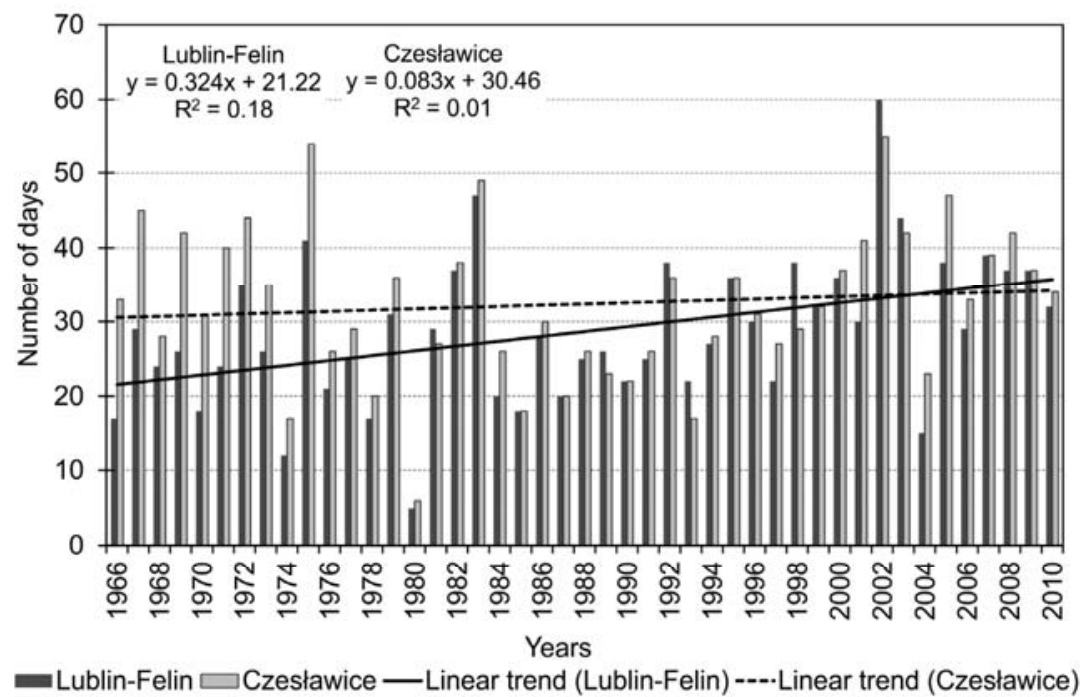

FIGURE 3. Long-term variability of the number of hot days in Lublin-Felin and Czesławice

TABLE 3. Characteristics of very hot days in Czesławice and Lublin-Felin

\begin{tabular}{|l|c|c|c|c|}
\hline \multirow{2}{*}{ Months } & \multicolumn{3}{|c|}{ Very hot days $\left(t_{\max }>30^{\circ} \mathrm{C}\right)$} \\
\cline { 2 - 5 } & \multicolumn{2}{|c|}{ Czesławice } & \multicolumn{2}{c|}{ Lublin-Felin } \\
\cline { 2 - 5 } & sum & mean & sum & mean \\
\hline May & 2 & 0.0 & 4 & 0.1 \\
\hline June & 15 & 0.3 & 20 & 0.4 \\
\hline July & 98 & 2.2 & 96 & 2.1 \\
\hline August & 86 & 1.9 & 70 & 1.6 \\
\hline Sum / Mean & 201 & 4.5 & 190 & 4.2 \\
\hline
\end{tabular}

(17 cases in Czesławice and 19 in Lublin-Felin). More than 10 very hot days also occurred in 1971, 1992, 2001, 2006, and 2010. The mean number of such days in the study period was approximate to the values recorded in Central Poland (Koźmiński and Michalska 2011). In Poland, very hot days were the most numerous in 2006, exceeding 20, and locally even 25 days (Cebulak and Limanówka 2007, Koźmiński and Michalska 2011).
In Lublin-Felin and Czesławice, the year 2006 was distinguished by the highest number of very hot days in July in the multiannual period. The maximum from 1994 in relation to all months, however, was not exceeded.

In May, only single cases of very hot days were recorded - in Czesławice in 1969 and 2003, and in Lublin-Felin in 1998 and 2005. Also in June, such days were rather seldom, and only occurred in the vicinity of both of the meteorological stations in 10 years of the analysed multiannual period. The highest number of very hot days was recorded in July (Fig. 2, Table 3), with a maximum in 2006 (10 days in Czesławice and 13 in Lublin-Felin) and 1994 (9 and 10 days, respectively). In August, the mean number of very hot days was slightly lower than that in July. The maximum number of very hot days in August was observed in 
1992 (10 cases), when the latest term of occurrence of a day with $t_{\text {max }}>30^{\circ} \mathrm{C}$ was recorded on $31^{\text {st }}$ August.

The assessment of the tendencies in the variability of very hot days showed a statistically significant upward trend. Both in Czesławice and Lublin-Felin, the trend coefficients were statistically significant ( $\alpha=0.01)$, confirming an increase in the number of very hot days by approximately 1 and 2 days over 10 years, respectively (Fig. 4). A considerable increase in their frequency was also observed in other regions of Poland and Europe (Kuchcik 2006, Twardosz 2009, Kossowska-Cezak and Twardosz 2012, Bielec-Bąkowska and Piotrowicz 2013). For example, their substantially more frequent occurrence in Warsaw was evidenced by Kossowska-Cezak (2010). According to the author, an average of 3 days more occurred there in the last two decades than in the multiannual 1951-2000.

Sequences of very hot days with exceeded assumed threshold air temperature values are of importance for the issue discussed. As shown in Table 4, such days usually occurred on one or two days. Heat waves (at least 3 days with $t_{\max }>30^{\circ} \mathrm{C}$ ) appeared rather seldom -18 such cases were observed in Czesławice, and 19 in Lublin-Felin. It is important that on both of the meteorological stations, only two of all of the cases of heat waves occurred before 1990. The highest number of heat waves was recorded in Lublin-Felin in 2010, when one sequence of three, and two sequences of four very hot days occurred. Heat waves with a duration from 4 to 7 days also occurred in 1992, 2001, and 2006. The longest sequence of 15 very hot days was recorded on both of the weather

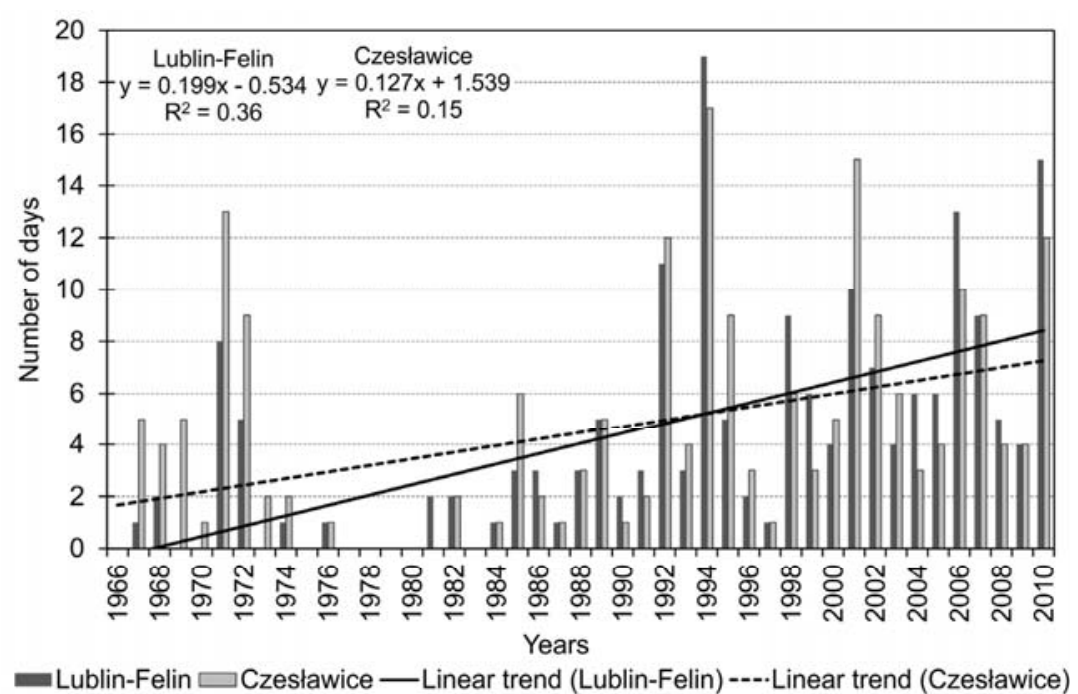

FIGURE 4. Long-term variability of the number of very hot days in Lublin-Felin and Czesławice 
TABLE 4. The number of consecutive very hot days in Czesławice and Lublin-Felin

\begin{tabular}{|c|c|c|}
\hline $\begin{array}{c}\text { Series } \\
\text { duration } \\
\text { (in days) }\end{array}$ & Czesławice & Lublin-Felin \\
\hline 1 & 54 & 59 \\
\hline 2 & 32 & 21 \\
\hline 3 & 7 & 6 \\
\hline 4 & 7 & 9 \\
\hline 5 & $\cdot$ & $\cdot$ \\
\hline 6 & 2 & 1 \\
\hline 7 & 1 & 2 \\
\hline $8-14$ & $\cdot$ & $\cdot$ \\
\hline 15 & 1 & 1 \\
\hline
\end{tabular}

stations in 1994 (from 24 $4^{\text {th }}$ July to $7^{\text {th }}$ August). The absolute maximum of air temperature in Czesławice $\left(34.7^{\circ} \mathrm{C}\right.$ ) was measured on the hottest day of the sequence ( $31^{\text {st }}$ June). In 1994, its extreme values were also recorded in Wrocław and Słubice: $37.8^{\circ} \mathrm{C}$ and $39.5^{\circ} \mathrm{C}$, respectively (Ustrnul and Czekierda 2002, Kuchcik 2006).
The determination of the atmospheric circulation conditions of the studied phenomenon involved the assessment of the effect of airflow direction on the occurrence of days with very high air temperature in Lublin-Felin and Czesławice. In the period from June to August, the highest conditional probability of occurrence of a day with $t_{\max } 25.1-30.0^{\circ} \mathrm{C}$ corresponded to circulation types from the anticyclonic class (31\% in Lublin-Felin and 34\% in Czesławice), followed by transitional (28 and $31 \%$, respectively), and the lowest to the cyclonic class (20 and $22 \%$ ). The highest values of this characteristic concerned days with southerly (46 and $48 \%$ ), easterly (41 and 42\%), southwesterly (39 and 40\%), and south-easterly airflow (38 and 44\%) - Figure 5 . Their occurrence was the least favoured by advection from the north and north-
FIGURE 5. The conditional probability [\%] of the occurrence of hot (a and b) and very hot days (c and d) according to the airflow direction (June - August)
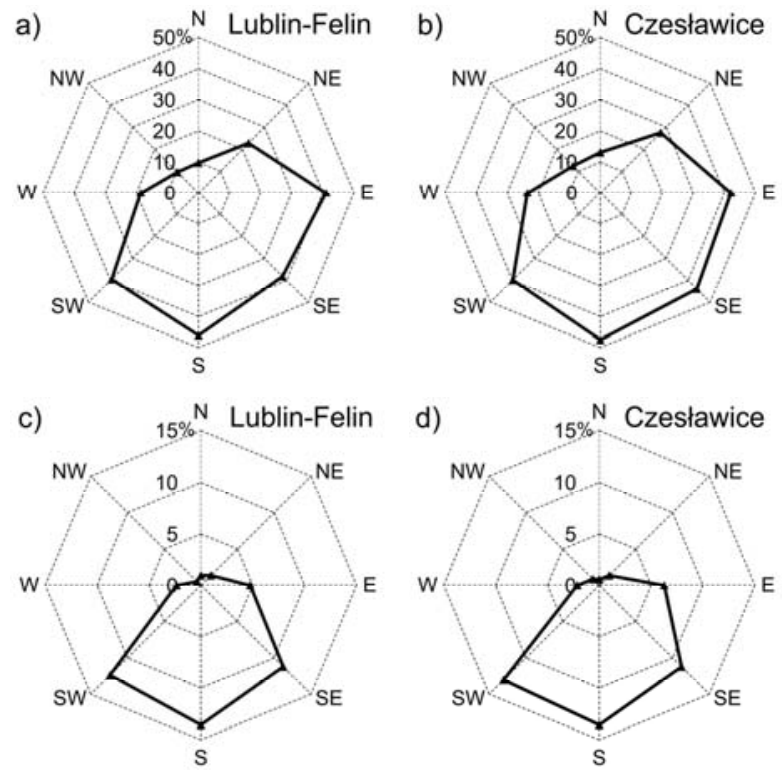
-west $(<13 \%)$. The highest conditional probability values were determined for type Sa, So, SWa, SEo, SWo and SEa, the lowest for Nc, NWc and NWo (Table 5). and south-eastern $(11 \%)$ air advection (Fig. 5). This is in accordance with the findings by Ustrnul and Czekierda (2002), who analysed circulation condi-

TABLE 5. The conditional probability [\%] of the occurrence of hot and very hot days in Lublin-Felin and Czesławice according to circulation types (CTs) over Lublin Region (June - August)

\begin{tabular}{|c|c|c|c|c|c|c|c|c|c|}
\hline \multirow[b]{2}{*}{ CTs } & \multicolumn{2}{|c|}{ Hot days } & \multicolumn{2}{|c|}{ Very hot days } & \multirow[b]{2}{*}{ CTs } & \multicolumn{2}{|c|}{ Hot days } & \multicolumn{2}{|c|}{ Very hot days } \\
\hline & Lublin & $\begin{array}{c}\text { Czesła- } \\
\text { wice }\end{array}$ & Lublin & $\begin{array}{c}\text { Czesła- } \\
\text { wice }\end{array}$ & & Lublin & $\begin{array}{c}\text { Czesła- } \\
\text { wice }\end{array}$ & Lublin & $\begin{array}{c}\text { Czesła- } \\
\text { wice }\end{array}$ \\
\hline $\mathrm{Nc}$ & 7.7 & 6.5 & . & $\cdot$ & $\mathrm{Sa}$ & 52.8 & 48.6 & 18.1 & 22.2 \\
\hline $\mathrm{N}_{0}$ & 11.9 & 15.8 & 2.8 & 1.1 & SWc & 31.9 & 36.2 & 12.1 & 10.6 \\
\hline $\mathrm{Na}$ & 9.7 & 17.0 & $\cdot$ & . & $\mathrm{SW}_{0}$ & 45.3 & 44.4 & 12.8 & 12.8 \\
\hline $\mathrm{NEc}$ & 13.4 & 20.2 & . & . & SWa & 48.8 & 39.0 & 12.2 & 22.0 \\
\hline $\mathrm{NE}_{0}$ & 22.1 & 29.2 & 3.6 & 3.1 & $\mathrm{Wc}$ & 15.4 & 17.4 & $\cdot$ & $\cdot$ \\
\hline $\mathrm{NEa}$ & 29.1 & 30.1 & . & & $\mathrm{W}_{0}$ & 21.8 & 28.5 & 1.8 & 1.8 \\
\hline Ec & 33.7 & 31.5 & 2.2 & 2.2 & $\mathrm{Wa}$ & 20.0 & 30.0 & 11.7 & 10.0 \\
\hline $\mathrm{E}_{0}$ & 41.6 & 41.0 & 5.6 & 8.1 & NWc & 6.8 & 10.0 & $\cdot$ & . \\
\hline $\mathrm{Ea}$ & 43.8 & 47.6 & 5.2 & 6.7 & $\mathrm{NW}_{0}$ & 9.7 & 11.9 & . & . \\
\hline SEc & 33.0 & 37.1 & 7.2 & 8.2 & NWa & 14.5 & 17.7 & 1.6 & 2.4 \\
\hline $\mathrm{SE}_{0}$ & 37.0 & 48.0 & 16.0 & 15.0 & A & 31.6 & 34.0 & 3.2 & 4.5 \\
\hline SEa & 43.5 & 46.1 & 10.4 & 10.4 & $\mathrm{C}$ & 21.1 & 21.6 & 2.8 & 2.3 \\
\hline $\mathrm{Sc}$ & 44.1 & 47.1 & 5.9 & 4.9 & $X$ & 37.8 & 38.4 & 6.4 & 7.0 \\
\hline$S_{0}$ & 43.4 & 47.2 & 17.9 & 16.0 & & & & & \\
\hline
\end{tabular}

Very hot days were usually expected during the occurrence of circulation types from the transitional class (conditional probability $6 \%$ ), especially with southern $(14 \%)$, south-western $(12 \%)$, tions of extreme air temperature values in Poland. The highest values of this characteristic were determined for types Sa, So, SWa and SEo (Fig. 6, Table 5). During the occurrence of types $\mathrm{Na}, \mathrm{Nc}$,

a

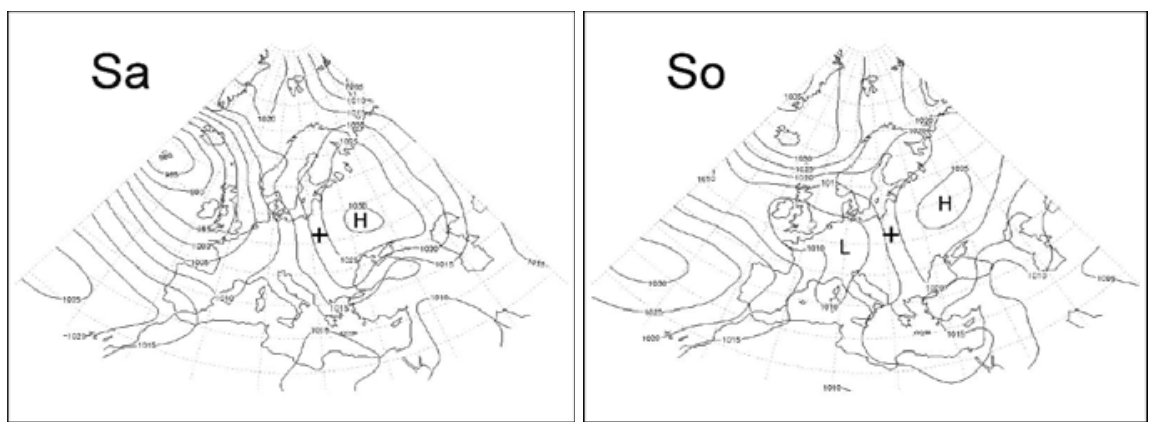

FIGURE 6. Circulation types with the highest probability of occurrence of days with $t_{\max }>30^{\circ} \mathrm{C}$ in Lublin-Felin and Czesławice (a) 
b

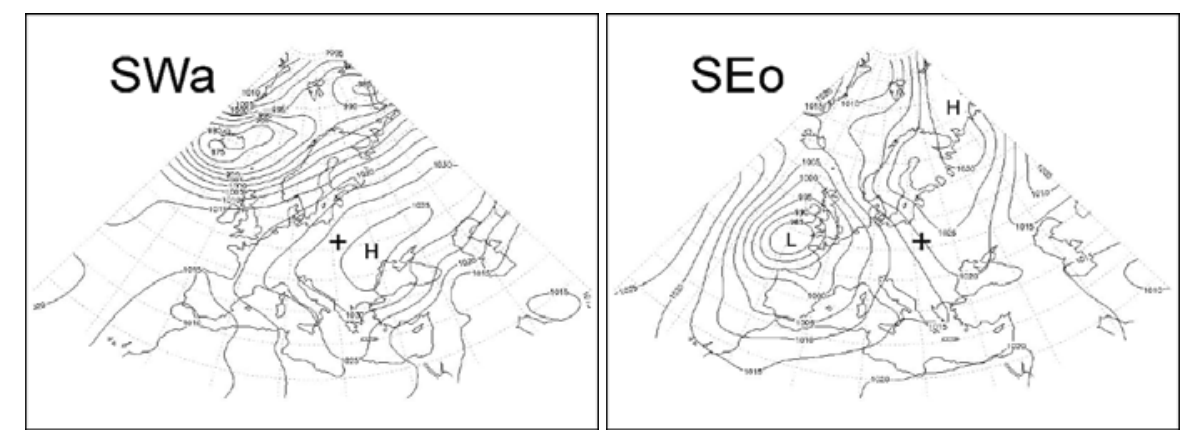

FIGURE 6, continued. Circulation types with the highest probability of occurrence of days with $t_{\max }>30^{\circ} \mathrm{C}$ in Lublin-Felin and Czesławice (b)

$\mathrm{NEa}, \mathrm{NEc}, \mathrm{Wc}, \mathrm{NWc}$ and NWo, no cases of very hot days were recorded in Lublin-Felin and Czesławice.

\section{CONCLUSIONS}

1. The analysis of the temporal variability of very hot days in Lublin-Felin and Czesławice showed an increase in the frequency of their occurrence over the recent years. This is in accordance with observations on the majority of meteorological stations in Poland.

2. The occurrence of increasingly long sequences of very hot days was recorded, with higher maximum air temperature values. In the period from 1966 to 2010, only two out of almost 20 cases of heat waves occurred before 1990 .

3. The highest probability of occurrence of hot and very hot days was determined for anticyclonic and transitional circulation types with air advection from the southern sector, i.e. Sa, So, SWa and SEo.
4. The differences between the two weather stations, determined over the last two decades, can result from an increase in the contribution of anthropogenic areas in the vicinity of Felin district in Lublin, related to the effect of the so-called urban heat island.

5. A further increase in the number of very hot days in Czesławice can considerably affect the health and well-being of tourists and patients of the nearby health resort in Nałęczów.

\section{REFERENCES}

BARTOSZEK K. 2012: Calendar of circulation types over Lublin Region. University of Life Sciences in Lublin, Department of Agrometeorology, Lublin. Retrieved from http:// www.krzysztof.bartoszek.up.lublin.pl (access 18.9.2013).

BIELEC-BĄKOWSKA Z., PIOTROWICZ K. 2013: Temperatury ekstremalne $\mathrm{w}$ Polsce $\mathrm{w}$ latach 1951-2006 [Extreme temperatures in Poland 1951-2006]. Prace Geograficzne 132, 59-98 (Engl. summ.).

BŁAŻEJCZYK K., McGREGOR G. 2007: Warunki biotermiczne a umieralność $\mathrm{w}$ wybranych aglomeracjach europejskich [Biothermal conditions and mortality in selected European agglomerations]. Przeglad Geograficzny 79 (3-4), 627-649 (Engl. summ.). 
CEBULAK E., LIMANÓWKAD. 2007: Dni z ekstremalnymi temperaturami powietrza [Days with extreme air temperatures in Poland]. In: Piotrowicz K., Twardosz R. (Eds). Wahania klimatu $\mathrm{w}$ różnych skalach przestrzennych i czasowych [Climate fluctuations at different spatial and temporal scales]. IGiGP UJ w Krakowie, 185-194 (Engl. summ.).

FILIPIUK E., KASZEWSKI B.M. 2000: Hot and cold summer in Central Europe (1871-1990). Prace Geograficzne 108, 149-154.

KASZEWSKI B.M., SIWEK K., SIŁUCH M., GLUZA A. 2007: Ekstremalne wartości wybranych charakterystyk termicznych w Lublinie (1951-2004) [Extreme values of selected thermal characteristics in Lublin (1951-2004)]. In: J. Szkutnicki, U. Kossowska-Cezak, E. Bogdanowicz, M. Ceran (Eds). Cywilizacja i żywioły [Civilization and elements]. PTGeof., IMGW, Warszawa, 118-126 [Engl. summ.].

KOSSOWSKA-CEZAK U. 2010: Występowanie pogody gorącej w Warszawie (1951-2009) [Occurrence of heat weather in Warsaw (1951-2009)]. Przeglad Geofizyczny 60 (1-2), 61-75.

KOSSOWSKA-CEZAK U., TWARDOSZ R. 2012: Niezwykle gorące miesiące i sezony letnie w Europie Środkowej i Wschodniej (1951-2010). Część I. Niezwykle gorące miesiące letnie [Exceptionally hot summer months and seasons in Central and Eastern Europe (1951-2010). Part I. Exceptionally hot summer months]. Przeglad Geofizyczny 57 (3-4), 299-324 (Engl. summ.).

KOŹMIŃSKI C., MICHALSKA B. 2011: Zmienność liczby dni zimnych, chłodnych, ciepłych gorących i upalnych w Polsce w okresie kwiecień-wrzesien [Variability in the numbers of cold, cool, warm, hot, and very hot days in Poland in the April-September period]. Przeglad Geograficzny 83 (1), 91-107 (Engl. summ.).

KUCHCIK M. 2006: Fale upałów w Polsce w latach 1993-2002 [Heat waves in Poland over the period 1993-2002]. Przeglad Geograficzny 78 (3), 397-412 (Engl. summ.).

LIPA J. 2008: Następstwa zmian klimatycznych dla kwarantanny i ochrony roślin [Conse- quences of climate change for quarantine and plant protection]. Postęy w Ochronie Roślin 48 (3), 777-791 (Engl. summ.).

MORAK S., HEGERL G.C., KENYON J. 2011: Detectable regional changes in the number of warm nights. Geophysical Research Letters 38 (17). DOI 10.1029/2011GL048531.

MORAWSKA-HORAWSKA M. 1991: Fale ciepła i chłodu w Krakowie w stuleciu 1881-1980 [Warm and cold waves in Cracow in the period 1881-1980]. Wiadomości IMiGW 14 (1-4), 127-136.

REBETZ M., DUPONT O., GIROUD M. 2009: An analysis of the July 2006 heatwave extent in Europe compared to the record year of 2003. Theoretical and Applied Climatology 95 (1-2), 1-7.

TWARDOSZ R. 2009: Fale niezwykłych upałów w Europie na początku XXI wieku [Extraordinary heat waves in $21^{\text {st }}$ century Europe]. Przeglad Geofizyczny 54 (3-4), 193-204 (Engl. summ.).

USTRNUL Z., CZEKIERDA A. 2002: Ekstremalne wartości temperatury powietrza $\mathrm{W}$ Polsce w drugiej połowie XX wieku na tle warunków cyrkulacyjnych [Extreme air temperature values in Poland in the second half of the $20^{\text {th }}$ century against the background of circulatory conditions]. Wiadomości IMiGW 25 (4), 3-21 (Engl. summ.).

VOSE R.S., EASTERLING D.R., GLEASON B. 2005: Maximum and minimum temperature trends for the globe: An update through 2004. Geophysical Research Letters 32 (23). DOI 10.1029/2005GL024379.

ŻMUDZKA E. 2004: Tło klimatyczne produkcji rolniczej $\mathrm{w}$ Polsce $\mathrm{w}$ drugiej połowie $\mathrm{XX}$ wieku [Climatic background of the agricultural production in Poland in the second half of $20^{\text {th }}$ century]. Acta Agrophysica 3 (2), 399-408 (Engl. summ.).

Streszczenie: Wystepowanie pogody upalnej $w$ Lublinie $i$ Czestawicach oraz jej uwarunkowania cyrkulacyjne (1966-2010). W pracy scharakteryzowano występowanie dni gorących $\left(t_{\max } 25,1-30,0^{\circ} \mathrm{C}\right) \mathrm{i}$ upalnych $\left(t_{\max }>30^{\circ} \mathrm{C}\right) \mathrm{w} \mathrm{Lu}-$ blinie (dzielnica Felin) oraz Czesławicach w latach 1966-2010. Analizie poddano wieloletnią 
zmienność tego rodzaju dni oraz czas trwania fal upałów. Określono także ich uwarunkowania cyrkulacyjne, wskazując typy cyrkulacji, podczas których prawdopodobieństwo pojawienia się dni gorących i upalnych było największe. Na badanym obszarze dni gorące występowały od kwietnia do września, a upalne od maja do sierpnia, w obu przypadkach z największą częstością w lipcu. W okresie 1991-2010 notowano zdecydowanie większą liczbę przypadków dni upalnych niż w latach 70. i 80. XX wieku. Ponadto pojawiały się one w coraz dłuższych sekwencjach, co przyczyniało się do coraz częstszego występowania niekorzystnych warunków termiczno-wilgotnościowych w okresie wegetacji roślin uprawnych. Największym prawdopodobieństwem pojawiania się dni gorących i upalnych odznaczały się typy cyrkulacji warunkujące napływ powietrza $\mathrm{z}$ sektora południowego, najmniejszym zaś $\mathrm{z}$ północnego. Przy dalszym zachowaniu tendencji wzrostowej dni upalnych wzrośnie także ryzyko oddziaływania tego rodzaju niekorzystnych warunków termicznych na zdrowie i samopoczucie turystów oraz kuracjuszy przebywających w uzdrowisku w Nałęczowie.
Stowa kluczowe: dni gorące, dni upalne, fale upałów, typy cyrkulacji, adwekcja powietrza

MS. received February 2016

\section{Authors' address:}

Krzysztof Bartoszek

Uniwersytet Marii Curie-Skłodowskiej

w Lublinie

Wydział Nauk o Ziemi i Gospodarki Przestrzennej

Zakład Meteorologii i Klimatologii

al. Kraśnicka 2 cd, 21-718 Lublin

Poland

e-mail: krzybart@gmail.com

Alicja Węgrzyn

Uniwersytet Przyrodniczy w Lublinie

Wydział Agrobioinżynierii

Zakład Agrometeorologii

ul. Akademicka 15, 20-950 Lublin

Poland

e-mail: alicja.wegrzyn@up.lublin.pl 